\title{
Botanical Preferences of Africanized Bees (Apis mellifera) on the Coast and in the Atlantic Forest of Sergipe, Brazil
}

by

Júlio César Melo Poderoso ${ }^{1}$; Maria Emilene Correia-Oliveira ${ }^{2 *}$; Luan Carlos Paz $^{3}$; Tácito Moreira da Silva e Souza ${ }^{3}$; Franz Zirena Vilca ${ }^{4}$; Priscylla Costa Dantas ${ }^{5}$ \& Genésio Tâmara Ribeiro ${ }^{3}$

\section{ABSTRACT}

Pollen analysis in honey can be used as an alternative method to research into flowers visited by bees in an area. This study aimed to indentify the main floral families in honey from apiaries in the Atlantic Forest and Sergipe state coast. Honey samples from these apiaries were studied, as well as plants that grow around them, which can be used as a source of foraging for bees. The palynological technique was used to compare the pollen content of honey samples with the pollen grains from leaves of plants found in the vicinity of the apiaries to assess whether they had been visited by bees. The results of studies in both sites were similar in terms of incompatibility of families found in the apiary vicinity and honey. Thus, it was possible to observe that in honey samples from the coast and in the remaining Atlantic forest, the number of families was greater than the number of families found in the apiary vicinity, which highlights the diversity of plants visited by bees and a possible expansion of the visited area for food search. This diversity suggests an adaptive foraging behavior to plant resources available in the environment, which may facilitate the pollination of these botanical families and consequently improve their genetic quality.

\footnotetext{
${ }^{1}$ Programa de Pós-graduação em Entomologia da Universidade Federal de Viçosa, 36571-000, Viçosa, Minas Gerais, Brasil

${ }^{2}$ Programa de Pós-graduação em Entomologia da Escola Superior de Agricultura Luiz de Queiroz, Universidade de São Paulo, 13418-900, Piracicaba, São Paulo, Brasil

${ }^{3}$ Departamento de Engenharia Florestal da Universidade Federal de Sergipe, 49100-000, São Cristóvão, Sergipe, Brasil

${ }^{4}$ Programa de Pós-graduação em Ecologia Aplicada da Escola Superior de Agricultura Luiz de Queiroz e Centro de Energia Nuclear na Agricultura, Universidade de São Paulo, Piracicaba, São Paulo, Brasil

${ }^{5}$ Programa de Pós-graduação em Agronomia/Entomologia da Universidade Federal de Lavras, 3037, 37200-000, Lavras, Minas Gerais, Brasil

'Corresponding author: emilenebio@hotmail.com
} 
Key-words: palynology, food preferences, honey, pollen

\section{INTRODUCTION}

Bees visit plants searching for pollen, nectar and resins to maintain their colonies. The workers of Apis mellifera L. move from flower to flower collecting food for the larvae and adults of the colony (Wcislo \& Cane 1996).

The pollen is the only protein source in the bees' diet, and it contains lipids, vitamins and minerals necessary for their development (Day 1990). The nectar, a substance secreted by glands called nectaries, is a sugary compound that attracts animals (Raven et al. 1992), which may contain varying amounts of sugars, according to the species and other environmental factors (Crane 1999). There are other substances such as organic acids, ethereal oils, polysaccharides - mainly dextrin, proteins, enzymes, boron and alkaloids - provided by the nectar (Percival 1965).

The visited plants are an essential resource for the bees and knowing them constitutes a basic tool for the development of apiculture (Pearson \& Braiden 1990). The composition of the bee flora of a region is the main factor for the installation and development of an apiary, as it influences the number of hives to be installed and the honey production of the apiary (Ashman et al.2004; Biesmeijer et al. 2006; Williams 1994; Westerkamp \& Gottsberger 2000).

Pollen analysis in honey can be used as an alternative to identify the flowers visited by bees in an area (Ramírez-Arriaga \& Martínez-Hernández 1998). One way to identify species visited by bees is through palynology, as the pollen spectrum obtained through this analysis shows the distribution of pollen sources and honey plants where the apiary is installed (Durkee 1971).

The flora of a site is composed of different species at distinct levels of importance; therefore, studying them is crucial as it provides information that enables the adoption of an optimal apiary management. This study aimed to identify the main floral families present in honey and apiaries located in biomes in the Atlantic Forest and on the coast of the state of Sergipe - Brazil.

\section{MATERIAL AND METHODS}

\section{Experimental area}

The study was conducted in the municipality of Pacatuba (11'36'15" S 
and $37^{\circ} 26^{\prime} 34 \mathrm{~W}$ ) at the "Tigre" apiary, representing the coastal area and in Japaratuba $\left(10^{\circ} 35^{\prime} 34^{\prime \prime} \mathrm{S} 36^{\circ} 56^{\prime} 24^{\prime \prime} \mathrm{O}\right)$ at the "Treze de Maio" apiary, representing the Atlantic Forest area.

Honey samples from these apiaries were studied, as well as plants that grow in their vicinity, which can be used as a source for bee foraging.

\section{Collection of samples}

The samples were collected during the harvest season of honey, which corresponded to the period from November 2009 to January 2010. A honey sample was obtained from each apiary, and at the same time, plants in full bloom were collected from a radius of one kilometer around the apiaries. Considering the four quadrants, a sample in each 100 meters was collected to represent the tree, shrub and/or herbaceous extracts of plants in full flower (Fig. 1).

The plant material collected was dried in an oven at $60 \pm 2^{\circ} \mathrm{C}$ for 48 hours to assemble the exsiccates and sampling of flower buds to make a comparative slide collection, using the acetolysis technique, by removing anthers and breaking pollen sacs, which were placed in test tubes and combined with $2 \mathrm{~mL}$ of acetic acid.

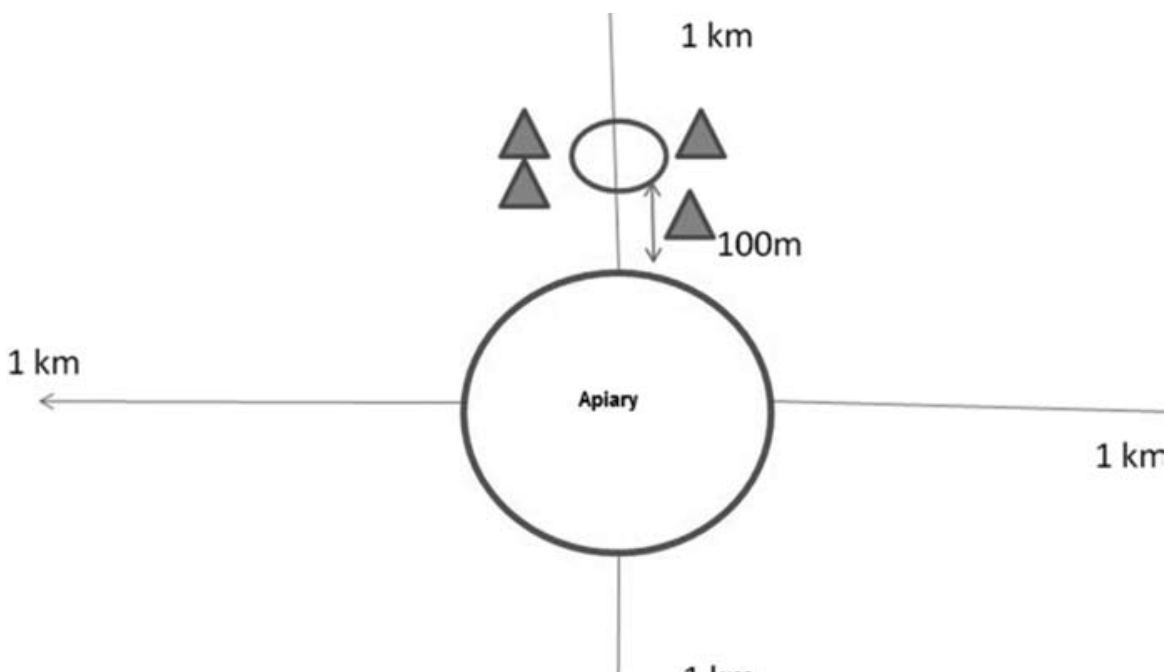

$1 \mathrm{~km}$

Fig, 1: Representation of the method of collection of botanical samples selected in apiaries. 


\section{Pollen Analysis}

This analysis consists of fossilizing the pollen grains for comparison with images on the database and botanical identification of plants that bees visited for nectar and pollen collection. Slides with samples of honey and anthers were made using the acetolysis technique and mounted in glycerol gelatin (Erdtman 1960; Barth \& Luz 1998; Terrab et al. 2003). The pollen analysis was carried out in the Laboratory of Agricultural and Forest Pests of the Federal University of Sergipe and the slides were sent to the Laboratory of Useful Insects of the College of Agriculture Luiz de Queiroz (ESALQ\USP) where they were micrographed by a digital system of photo documentation coupled to an optical microscope with $40 \mathrm{x}$ objective. The qualitative assessment was carried out with the identification of the botanical families and botanical genera. The quantitative analysis was performed by counting 900 pollen grains per sample. The pollen species classified as dominant accounted for $46 \%$, accessory between 15 to $45 \%$ and occasional lower than $15 \%$. The pollen type identification was carried out following image database and specialized bibliography.

After, the pollen content of the honey samples were compared with the pollen grains of plants collected in the vicinity of the apiary to assess whether they had been visited by bees.

\section{RESULTS}

Despite the representation of the Mimosaceae family as dominant, it had four different types of pollen grains, in other words, the pollen contained four different botanical species, Mimosa caesalpiniifolia $41 \%$, an unidentified species with 6\%, Mimosa scrabella with 5\% and M.pudica with 3\% altogether amounting $55 \%$ of the pollen in the honey. Although the Mimosaceae pollen grains are dominant, the honey is considered wild, once no species showed isolated dominance, i.e., presence greater than $45 \%$ of pollen grains (Figure 7 ).

\section{DISCUSSION}

Both the coastal area and in the remaining Atlantic Forest showed that in the honey samples, the number of flower families was greater than the number of families found in the apiary vicinity, which highlights the diversity 
of plants visited by bees and their possible expansion of the visited area to search for food.

The expansion of the area to collect pollen is related to the preference for a specific botanical family and for the cost-benetif to search for available sources to maintain the hive, a behavior that is transmitted to the workers. By finding the ideal source, of forage, bees may recruit nestmates and indicate the direction to these sources, increasing, therefore, the number of recruited bees (Queller and Strassmann 2002; Brockmann et al.2003; Breed et al.2004; Billen 2006; Pianaro et al. 2007).

The botanical families found in this study corroborate reports that Africanized bees in the neotropical region use primarily Asteraceae, Anacardiaceae, Euphorbiaceae, Lamiaceae, Fabaceae, Melastomataceae, Moraceae, Myrtaceae, Arecaceae, Rubiaceae and Solanaceae plant families (Almeida-Muradian $e t$ al.2005; Barth \& Luz 1998; Ramalho et al, 1990). The families visited by Apis mellifera are important sources of nectar and pollen. Moreover, the pres-

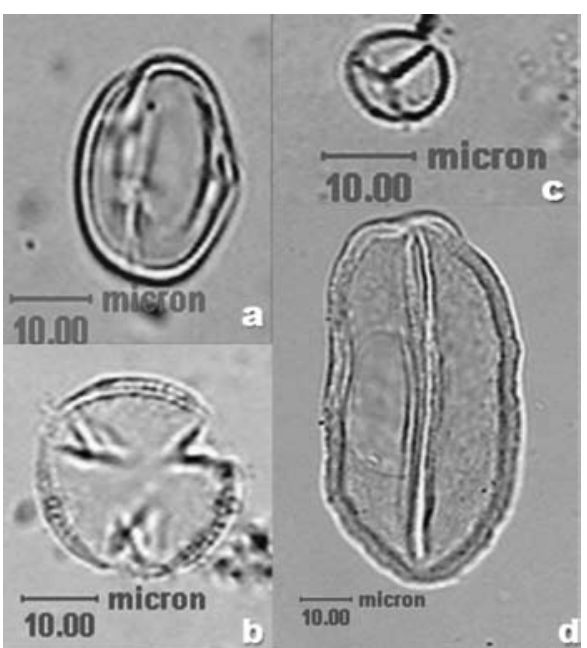

Fig. 2. Accessory pollen grains found in a sample of honey from the apiary Tigre, Pacatuba, SE; a. Fabaceae type Macropitilia; b. Leguminosae, Papilionoidae; c. Mimosaceae; d. Arecaceae, 40x magnification.

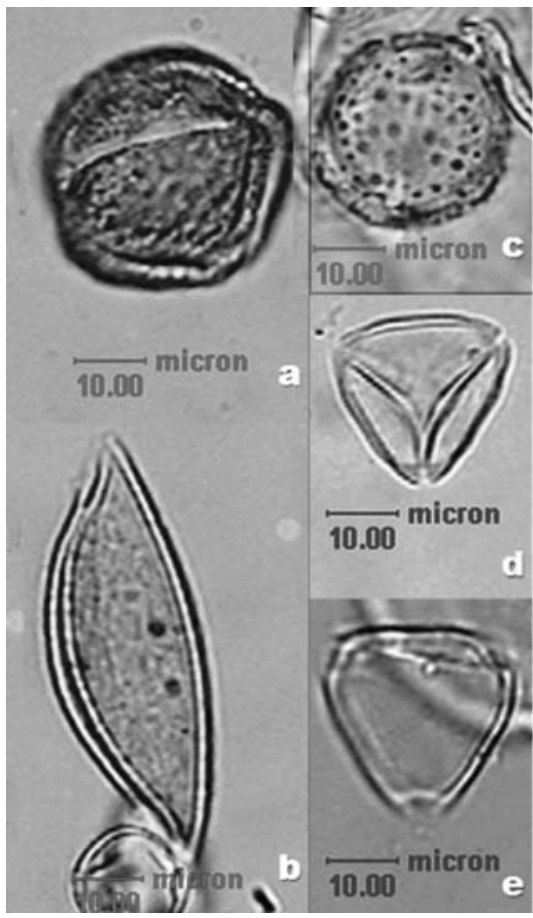

Fig. 3. Isolated pollen grains found in a sample of honey from the apiary Tigre Pacatuba, SE; a. Anacardiaceae; b. Araceae; c.Rubiaceae; d. Sapindaceae; e. Verbenaceae, 40x magnification. 


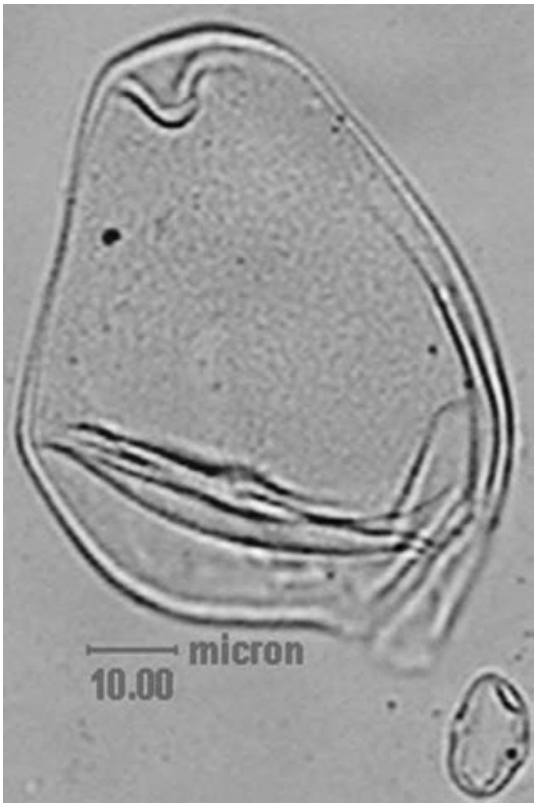

Fig. 4. Pollen of the Poaceae family (higher grain) and bottom right, the pollen of the family Cecropiaceae, 40x magnification.

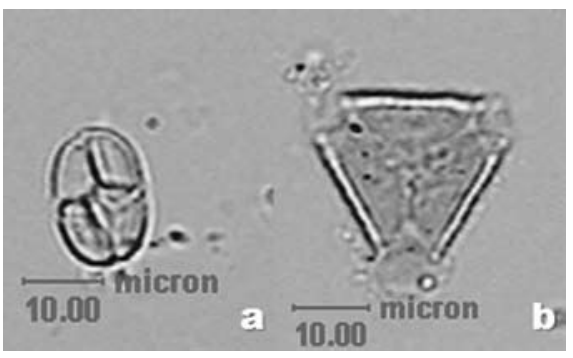

Fig. 5. Pollen grains in a sample of Pacatuba honey, SE. a. Pollen grains of the family Mimosaceae; b. Pollen grains of the family Myrtaceae, 40x magnification.

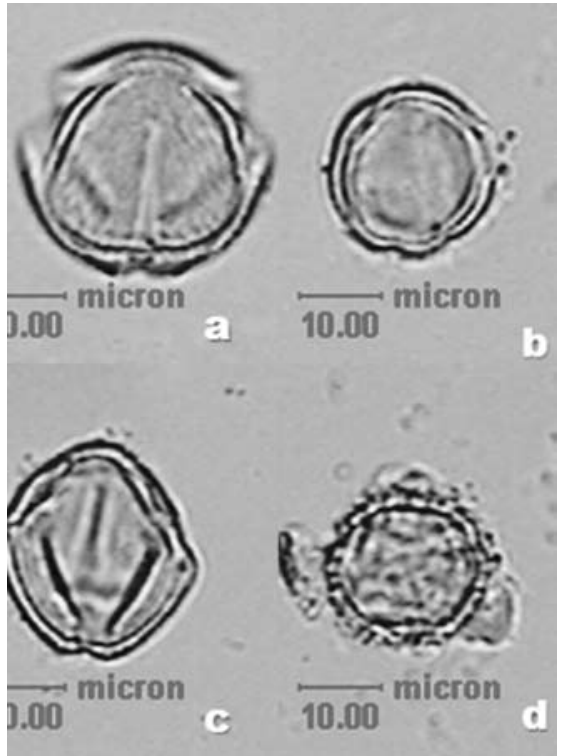

Fig. 6. Pollen grains in a sample of Pacatubahoney, SE. a. Anacardiaceae; b. Melastomataceae; c. Fabaceae; d. Rubiaceae, 40x magnification.

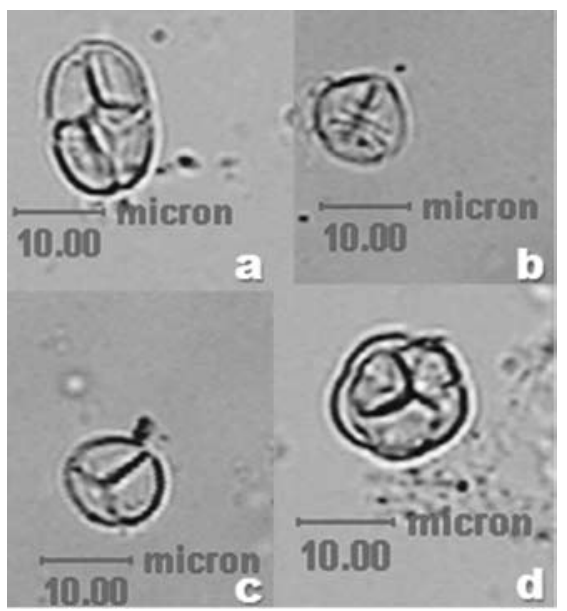

Fig. 7. Pollen types belonging to the family Mimosaceae found in honey samples. a. Mimosa caesalpiniifolia; b. Mimosa pudica; c. Mimosa scrabella; d. Mimosa sp. (unidentified species), with 40x magnification. 
ence of pollen of these families in the honey may be related to the abundance of available species in the flora (Quiroz-García et al. 2001). The presence of pollen of the family Arecaceae can be used as an indicator of geographical origin, since some species such as Cocos nucifera are easily found in the coastal or in cultivated areas.

The number of families visited by Apis mellifera is linked to their general characteristics, because theyvisit a large number of spices of plants, mainly small flowers, with dense and longer-lasting inflorescences and flowers with corollas long and wide or enough to allow access to the nectar (Heard 1999).

The pollen diversity found in the samples can be used as an indicator of wild honey, which can favor honey producers because of the diversity of aromas and flavors that they may have, due to a mixture of various nectars. This diversity suggests an adaptive behavior of plants to resources available in the environment, which may facilitate the pollination of these botanical families and consequently improve their genetic quality.

\section{ACKNOWLEDGMENT}

We are grateful to the "Conselho Nacional de Desenvolvimento Científico e Tecnológico (CNPq)”, Coordenação de Aperfeiçoamento de Pessoal de Nível Superior (CAPES).

\section{REFERENCES}

Almeida-Muradian, L.B., L.C. Pamplona, S. Coimbra, \& O.M. Barth 2005. Chemical composition and botanical evaluation of dried bee pollen pellets. Journal of Food Composition and Analysis 18:105-111.

Ashman, T. L., T.M. Knight, J.A. Steets, P. Amarasekare, M. Burd, D.R. Campbell, M.R. Dudash, M.O. Johnston, S.J. Mazer, R.J. Mitchell, M.T. Morgan, W.G. Wilson 2004. Pollen limitation of plant reproduction: ecological and evolutionary causes and consequences. Ecology 85: 2408-2421.

Barth, O.M. \& C.F.P. Luz 1998. Melissopalynological data obtained from a mangrove area near to Rio de Janeiro, Brazil. Journal of Apicultural Research 37: 155-163.

Biesmeijer, J.C., S.P.M. Roberts, M. Reemer, R. Ohlemüller, M. Edwards, T. Peeters, A.P. Schaffers, S.G. Potts, R. Kleukers, C.D. Thomas, J. Settele. \& W.E. Kunin 2006. Parallel declines in pollinators and insect-pollinated plants in Britain and the Netherlands. Science 313: 351-354.

Billen, J. 2006. Signal variety and communication in social insects. Proceedings of theNetherlands Entomological Society 17: 9-25. 
Breed, M.D., P.H. Diaz, \& K.D. Lucero 2004. Olfactory information processing in honeybee, Apis mellifera, nestmate recognition. Animal Behaviour 68: 921-928.

Brockmann, A., C. Groh, \& B. Fröhlich 2003. Wax perception in honeybees: contact is not necessary. Naturwissenschaften 90:424-427.

Buchmann, S. \& G. Nabhan, The forgotten pollinators. Island Press, Washington. 1996. $290 \mathrm{p}$.

Crane, E. The world history of beekeeping and honey hunting. Routledge: New York, 681p. 1999.

Day, S., R. Beyer,A. Mercer,\&S. Ogden 1990. The nutrient composition of honeybee-collected pollen in Otago, New Zealand. Journal of Apicultural Research 29: 138-146.

Durkee, L.H. 1971. A pollen profile from wooden bog in North-Central Iowa. Ecology. 52: 837-844.

Erdtman, G. 1960. The acetolysis method, a revised description. Svensk Botanisk Tidskrift 54:561-564.

Heard, T.A. 1999. The role of stingless bees in crop pollination. Annual Review of Entomology 44:183-206.

Kevan, P.G. 1999. Pollinators as bioindicators of the state of the environment: species, activity and diversity. Agriculture Ecosystems and Environment 77: 373-393.

Pearson, W.D.; \& V. Braiden. 1990. Seasonal pollen collection honeybees from grass/ shrub highlands in Canterbury, New Zealand. Journal of Apicultural Research 29: 206-213.

Percival, M.S. 1965 Floral Biology. Oxford: Pergamon.

Pianaro A., Flach A., Patricio E.F.L.R.A., Nogueira-Neto P. and Marsaioli A.J. 2007. Chemical changes associated with the invasion of a Melipona scutellaris colony by Melipona rufiventris workers. Journal of Chemical Ecology 33: 971-984Queller,

Strassmann, D.C. \& J.E. 2002. The many selves of social insects. Science 296:311-313.

Quiroz-García, D.L., E. MartíHernández, R. Palacios-Chávez, N.E. Galindo-Miranda 2001. Nest provisions and pollen foraging in three species of solitary bees (Hymenoptera:Apidae) from Jalisco, México. Journal of the Kansas Entomological Society 74:261-69.

Ramalho, M., V.L. Imperatriz-Fonseca, A. Kleinert-Giovannini 1990. Important bee plants for stingless bees (Melipona and Trigonini) and africanizad honeybees (Apis mellifera) in neotropical habitats: a Review. Apidologie 2: 469-488.

Ramírez-Arriaga E. and E. Martínez-Hernández 1998. Resources foraged by Euglossa atroveneta (Apidae, Euglossinae) at Union Juarez, Chiaps, Mexico. A palynological study of larval feeding. Apidologie 29: 347-359.

Raven, P.H., Evert, R.F. and Eichhorn, S.E. 1992. Biology of Plants, Fifth Edition. Worth Publishers, New York, 791 pp.

Terrab A., M.J. Díez, F.J. Heredia 2003. Palynological, physicochemical and colour characterisation of Moroccan honeys: I. River red gum (Eucalyptus camaldulensis Dehnh) honey. International Journal of Food Science \& Technology 38: 379-386. 
Waser, N.M., L. Chittka, M.V. Price, N.M. Willians, J. Ollerton 1996. Generalization in pollination systems, and why it matters. Ecological Society of America 77: 10431060.

Wcislo, W.T. and J.H. Cane 1996. Floral resource utilization by solitary bees (Hymenoptera: Apoidea) and exploitation of their stored foods by natural enemies. Annual Review of Entomology 41:257-286.

Westerkamp, C. and G. Gottsberger 2000. Diversity pays in crop pollination. CropScience 40: 1209-1222.

Williams, I.H. 1994. The dependences of crop production within the European Union on pollination by honey bees. Agricultural Zoology Reviews 6: 229-257. 
